\title{
Occupational training to reduce gender segregation: The impacts of ProJoven*
}

\author{
Hugo Ñopo \\ Banco Interamericano de Desarrollo \\ Miguel Robles \\ IFPRI \\ JAIME SAAVEDRA \\ Banco Mundial
}

\begin{abstract}
RESUMEN
Este artículo ilustra el proceso de evaluación de impacto del Programa de Capacitación Laboral Juvenil ProJoven. El programa provee a los beneficiarios un entrenamiento básico de tres meses en ocupaciones de baja calificación así como oportunidades para hacer prácticas. El diseño de ProJoven promueve la igualdad de género incentivando la participación femenina en ocupaciones tradicionalmente dominadas por los hombres y subsidiando la participación de madres de familia.

En complemento con el detallado trabajo de campo, el trabajo econométrico implementa un procedimiento de emparejamiento en dos etapas que incluye los propensity scores, en una primera etapa, y de género e ingresos laborales, en la segunda. El emparejamiento por género permite la identificación de impactos diferenciados para hombres y mujeres; por otro lado, el emparejamiento por ingresos ataca el problema de las caídas de Ashenfelter.

La evaluación muestra diferencias substanciales en los impactos del programa para hombres y mujeres. Dieciocho meses después de participar en el programa, la tasa de empleo de las mujeres aumentó aproximadamente $15 \%$ (frente a la tasa para los hombres, que se redujo $11 \%$ ), la segregación ocupacional por género se redujo en 30\% y el ingreso laboral de las mujeres aumentó en $93 \%$ (mientras que el de los hombres lo hizo en solo 11\%). Por otro lado, el costo de promover esta igualdad de género representó solo $1.5 \%$ del presupuesto total de ProJoven. Estos resultados sugieren que los programas de capacitación laboral que promueven la equidad de género tienen efectos desproporcionadamente positivos para mujeres en un mercado laboral con importantes diferencias de género.
\end{abstract}

Palabras clave: mercados de trabajo, capacitación laboral, jóvenes, América Latina.

\footnotetext{
* Research for this paper was done while the authors were researchers at GRADE (Grupo de Análisis para el Desarrollo). The authors are grateful to Milagros Alvarado, Miriam Camacho, Israel Gamarra and Teodoro Sanz at ProJoven. Deidre Ciliento, Juan Manuel García, Cristina Gómez and Manuel Hernandez provided valuable research assistance at different stages of this project. The comments of Lucas Higuera are additionally acknowledged. Correspondence can be addressed to Hugo Nopo (hugon@iadb.org).
} 


\begin{abstract}
This paper illustrates the process of program evaluation for ProJoven, the Peruvian youth labor training program. The program provides beneficiaries with basic three-month training in lowskill occupations and with internship opportunities. ProJoven's design promotes gender equality by encouraging female participation in training for traditionally male-dominated occupations and by providing subsidies so mothers with children can participate.

Complementing detailed fieldwork in search of the appropriate control group, the econometric work implements a two-stage matching procedure that includes propensity scores (on the first stage), and gender and labor income (on the second one). The matching on gender allows identification of differentiated program impacts on men and women. The matching on income attacks the problem of Ashenfelter's Dips.

The evaluation shows substantial differences in ProJoven's impact for men and women. Eighteen months after participation in the program, employment rates for women improved by about $15 \%$ (while employment for men reduced by $11 \%$ ), gender occupational segregation reduced by $30 \%$ and women's labor income improved by $93 \%$ (while men's earnings increased by $11 \%$ ).

On the other hand, the cost of the promotion of gender equality represented only $1.5 \%$ of ProJoven's total budget. These results suggest that labor training programs that promote equal gender participation have disproportionately positive effects on outcomes for women trainees in a labor market with substantial gender differences.
\end{abstract}

Keywords: labor markets, occupational training, youth, Latin America.

\title{
INTRODUCTION
}

Gender differences in the Peruvian labor market are notorious, especially among poor youth. Data from the 2000 National Household Survey reveal a general unemployment rate of $6.4 \%$, but the rate among the young (those under 25 years old) is $13.6 \%$. For 1986-2000 in Metropolitan Lima, Nopo (forthcoming) reports that the prevailing gender wage gap after controlling for observable human capital characteristics is highest among low-income individuals. At the bottom percentile of the income distribution, the hourly wages of men double those of women.

Such gender differences may arise because Peruvian labor markets do not provide equal opportunities to men and women or because opportunities are taken differently by gender. This paper examines that question by evaluating the impact in the largest Peruvian urban areas of ProJoven, a labor training program for poor youth. Evidence from the program shows that women who receive the opportunity to participate equally in the labor market benefit disproportionately more than men.

ProJoven encourages equal participation in its training courses, especially for traditionally male-dominated occupations. After three months of training, beneficiaries who pass competency tests graduate to a three-month internship with a local firm. The program tries to maximize success by reducing the mismatch between training and job placement, targeting only those occupations with proven market demand. 
Program results were assessed using data collected by ProJoven from a sample of beneficiaries and control individuals over time. Four measurements were taken: an initial baseline at the beginning of internships and three follow-ups at six, twelve and eighteen months after internships were completed. The search for controls involved detailed fieldwork in which ProJoven prematched individuals based on a small set of characteristics (gender, age, poverty, education and employment status).

When the information was collected, we performed the econometric analysis. Beneficiaries and controls were matched in a two-stage procedure, using the estimated propensity scores first and then gender and labor-income information. This allowed us to estimate differentiated gender impacts for ProJoven and to reduce the problem associated with Ashenfelter's Dip.

Literature on the gender effects of training in Latin America suggests that male workers benefit more than female workers from training, with the impact of training more pronounced for productivity than wages (López-Acevedo 2002). Our results support the latter conclusion, finding no substantial gender differences from training on hourly wages. However, we document important gender differences in outcomes for employment rates and occupational segregation. As a result, gender differences for the impact of training on total labor income are substantial.

\section{DESCRIPTION OF PROJOVEN}

ProJoven was created in 1996 as a pilot program sponsored by the Peruvian Ministry of Labor and Social Promotion (MTPE). Designed to provide training and internship opportunities to young Peruvian workers from low-income families by promoting successful training programs throughout the country, the program is expected to increase average wages and employment and to reduce gaps for young workers between jobs. It also has taken on the major goal of increasing female participation in the labor market, particularly in occupations traditionally filled by men.

The program finances the theoretical and practical training of selected beneficiaries. ProJoven contracts training entities, called ECAPs (Entidad de capacitación), to organize and offer training courses for which beneficiaries can enroll. ProJoven provides a structure by which ECAPs are motivated to design three-month training programs that match local firms' needs with the capabilities of participating trainees. ECAPs also must guarantee internship opportunities for participants who successfully complete their coursework.

The program targets young adults who are either unemployed or underemployed, have low educational levels and come from low-income families. Individuals who meet these specifications are selected through an accreditation process to participate in the program. Once selected, beneficiaries choose the training courses in which they want to enroll. 
ProJoven finances the training and provides a monthly stipend for trainees that covers transportation, meals and medical insurance. Additionally, to encourage their participation, women with children under the age of five receive a double stipend. Expenditures for mothers' subsidies represent $6.6 \%$ of total stipends, or less than $1.5 \%$ of ProJoven's total budget. When the coursework is over and tests are passed, beneficiaries intern at a firm under a youth temporary training contract. Internships last for at least three months, with firms paying interns a stipend at least equal to the minimum wage.

Since its inception, ProJoven has trained seven classes totaling 20,000 young workers through more than 240 training entities offering 1,027 courses. In its sixth class, ProJoven trained 3,610 youth individuals during 2000 in the five cities outlined in table 1 .

Table 1

ProJoven beneficiaries by city

\begin{tabular}{lcc}
\hline & Participants & Percent of trainees \\
\hline Arequipa & 400 & 11.1 \\
Chiclayo & 155 & 4.3 \\
Lima & 2,583 & 71.6 \\
Cusco & 127 & 3.5 \\
Trujillo & 345 & 9.6 \\
\hline Total & 3,610 & 100 \\
\hline
\end{tabular}

Source: ProJoven Database (MTPE 2002).

Elaboration: owner.

\section{PROGRAM EVALUATION}

\subsection{FIELDWORK}

Information was first collected in early March 2002, when the sixth class began. ${ }^{1}$ ProJoven designed a detailed process to collect data to evaluate the impact of its training on beneficiaries. First, individuals were selected using a stratified sampling method. Sampling was done independently in each city according to the following four categories: women aged 16 to 20, women aged 21 to 25, men aged 16 to 20 and men aged 21 to 25 . ProJoven representatives interviewed each sample enrollee using a questionnaire to elicit information about family income, previous training experience, educational level and labor history.

1 A class indicates a new group of beneficiaries selected to begin the training program. 
After collecting information on beneficiaries, ProJoven began to search for individuals to form a control group. The first criterion for controls was geographic. For each beneficiary ProJoven attempted to locate a control who lived nearby, preferably on the same block. This was done to increase the probability that beneficiaries and controls participated in the same labor market and had an equal opportunity to participate in the program. The second set of criteria included individual and characteristics. Controls and beneficiaries were paired by the following criteria:

- Having the same gender

- Being within one year of age of each other

- Belonging to families whose poverty level, measured in part by an ad hoc scale constructed by ProJoven, differed by no more than five points

- Having schooling levels that differed by no more than one academic year

- Having the same employment status (employed, unemployed, underemployed by earnings, underemployed by hours, inactive, discouraged or newcomer)

- Having a reported monthly income, for a principal activity as well as any secondary activity, that did not differ by more than 100 soles

- Having children whose number did not differ by more than one

When a control candidate satisfied these criteria, he/she was interviewed using the same questionnaire given to beneficiaries. ProJoven collected information for more than 1,000 beneficiaries and more than 3,000 controls to amass baseline data. For program evaluation, ProJoven then surveyed all individuals from the beneficiary and control samples at three intervals —at six, twelve, and eighteen months after the sample class had completed its internships-.

To alleviate the problem of attrition during the course of the surveys, ProJoven maintained a reserve group of beneficiaries and controls that were also interviewed but whose information was used only to replace data from individuals who did not complete the whole battery of measurements. If an individual from the sample could not be located for a follow-up interview, he/she was replaced with an individual from the reserve group with similar observable characteristics. The main source of attrition was migration, either national or international. When an individual moved to another location within the same city, ProJoven tried to locate the individual and apply the follow-up survey before turning to a replacement from the backup group.

The distribution by city of the samples of beneficiaries and controls, without considering the reserve group of beneficiaries, is shown in table 2 . With these samples of beneficiaries and controls collected by ProJoven, we proceeded to perform the econometric matching. 
Table 2

Sample sizes by city for beneficiaries and controls

\begin{tabular}{lcc}
\hline & Controls & Beneficiaries \\
\hline Arequipa & 293 & 205 \\
Chiclayo & 193 & 122 \\
Lima & 364 & 368 \\
Cusco & 190 & 117 \\
Trujillo & 494 & 202 \\
\hline Total & 1,534 & 1,014 \\
\hline
\end{tabular}

Source: ProJoven Database (MTPE 2002).

Elaboration: owner.

\subsection{THE ECONOMETRIC WORK}

We performed the econometric analysis on ProJoven's sample of beneficiaries and controls. The matching involved two steps: the preselection of control candidates (based on propensity scores) and the final selection (based on average hourly wages). The propensity scores were estimated for each city using the following variables:

- Gender

- Age

- Experience

- Schooling achievement

- Type of school (public or private)

- Previous training

- Marital status

- A dummy variable valued at 1 if the individual had children

- A dummy variable valued at 1 if the individual had secondary jobs

- Mothers' schooling

- Poverty of individuals' households

- Employment status during the previous three months

- Average hourly wages during the previous three months

Having estimated the propensities for each beneficiary, we preselected all the individuals in the control group with a propensity score that differed by no more than 0.05 from the score of their corresponding beneficiary. That is, we set a caliper of 0.05 for the matching on propensities. Among those who were preselected, we picked the three individuals with the same gender and the closest average logarithm of hourly wages as the beneficiary. Finally, we averaged the three chosen controls by applying a uniform kernel to their observable characteristics. It is important to note that the average wages 
of the last three months was also an explanatory variable in the estimation of propensity scores. We included it to avoid the possibility of omitted variable biases in the estimation of propensity scores.

The theoretical basis for the two-step matching procedure in the analysis is illustrated in figure 1 . The set of observable characteristics included in the matching score estimation are $n$-dimensional. Let us consider the projection of that space into a two-dimensional one, whose base is the set of characteristics $x_{1}$ and $x_{2}$. Points in the two-dimensional space represent the projections of the observations for beneficiaries and controls as the isopropensity lines shown below represent the projections of the isopropensity hyperplanes.

The beneficiary $A$ lies on an isopropensity that is close enough to the isopropensity for the control $B$ (or, equivalently, their propensity scores are close enough). If comparing solely the propensity scores would do the matching, $A-B$ could be a good match. But this neglects the possibility of better matches. The boxed neighborhoods of the beneficiary $A$ and the control $B$ contain other beneficiaries and controls that not only have similar propensity scores, but also have smaller differences in the actual observable matching variables $x_{1}$ and $x_{2}$. Combining the notions of propensity scores and nearest neighbors (on the space of characteristics, not in the propensity scores) promises to deliver better matches.

\section{Figure 1}

Illustration of a theoretical model for two-step matching of controls and beneficiaries

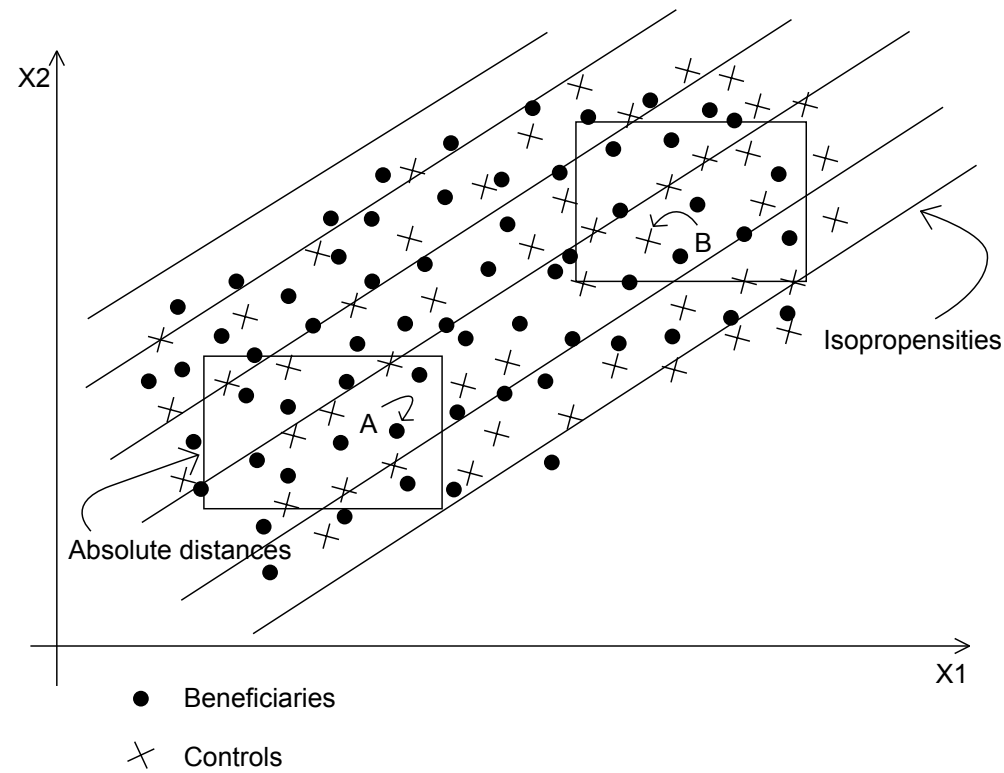

Source: own simulation.

Elaboration: owner. 
We combined the notions of matching on propensities and non-parametric nearest neighbors to produce a matched sample with smaller differences in observable characteristics ex ante. The second step in the matching criterion had a dual purpose: to reduce the presence of Ashenfelter's Dips ${ }^{2}$ in the evolution of beneficiaries' labor income and to allow differentiation of program impacts by gender. Figures $2 a$ and $2 b$ show density functions for the propensity scores for beneficiaries and controls before and after matching. Note the complete overlap of the beneficiaries' and controls' supports for the propensity scores. The effectiveness of matching is suggested by the proximity of the density functions for matched beneficiaries and controls.

Finally since the distribution of matched beneficiaries by city does not necessarily reflect the distribution of all beneficiaries, expansion factors were applied to the matched observations to convert the sample into one that is representative of the whole beneficiary population. As a result, the expanded sample of matched beneficiaries and controls shows average characteristics that, being similar to each other, are also similar to the characteristics of the beneficiary population. Some basic characteristics are explored next. Since $52 \%$ of beneficiaries are women, the matched sample corresponds to this percentage (table 3).

Figure 2

Density functions for the estimated propensities of being a beneficiary

a. Comparing unmatched beneficiaries and controls

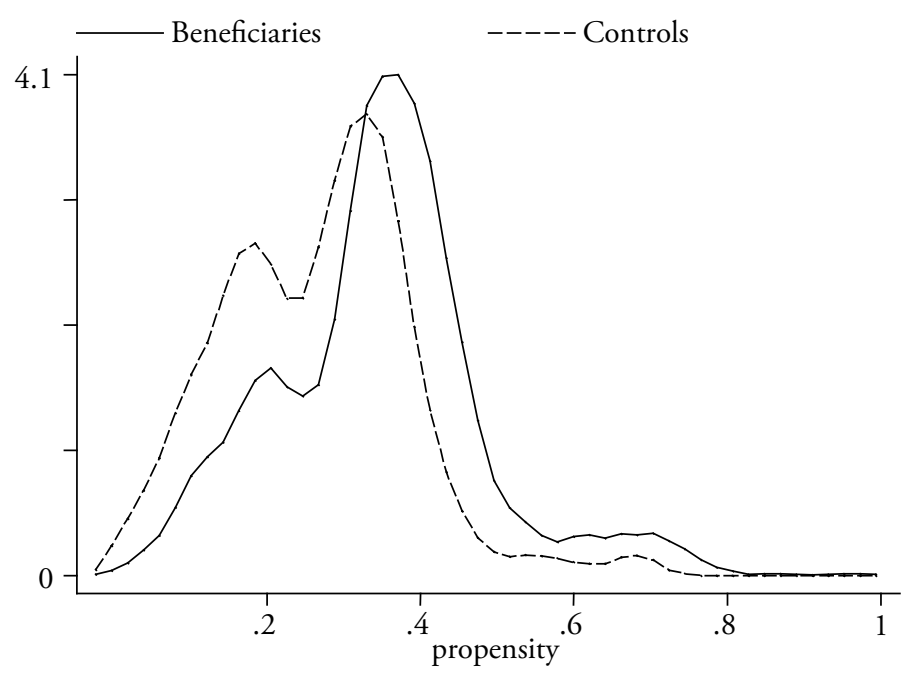

2 Ashenfelter (1978) pointed out that in this type of training program, beneficiaries' earnings are affected negatively prior to entering the program. See Heckman and Smith (1999) for additional details. Specific to ProJoven, some beneficiaries chose to reduce hours worked to free up time to complete the application process, while others stopped working in anticipation of being admitted to training. 


\section{b. Comparing matched beneficiaries and controls}

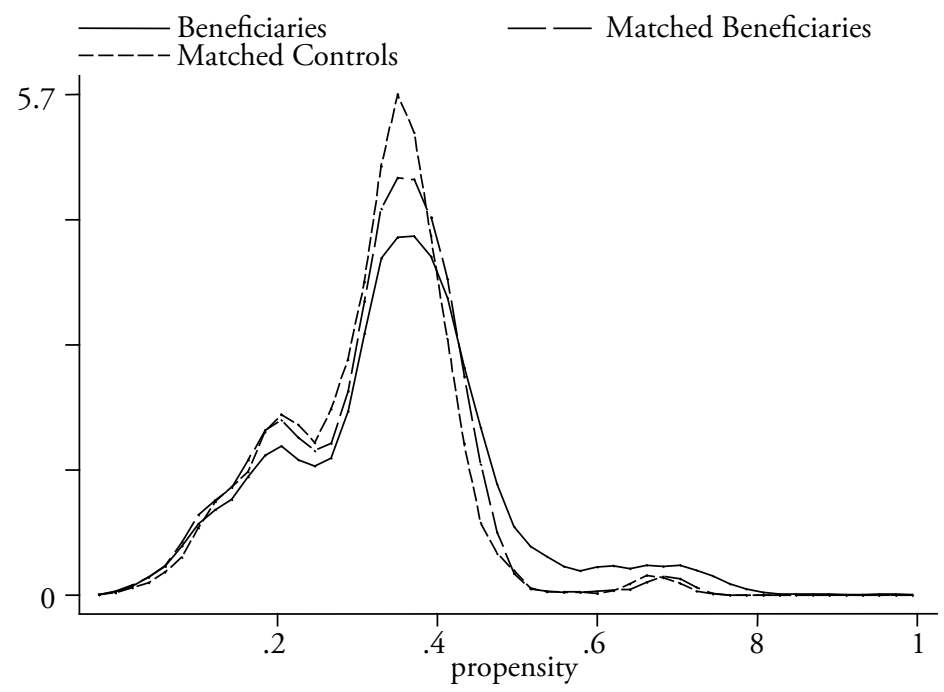

Source: ProJoven Database (MTPE 2002).

Elaboration: owner.

Table 3

Distribution by sex, expanded matched sample (in percent)

\begin{tabular}{lccc}
\hline & \multicolumn{2}{c}{ Prematched sample (\%) } & $\begin{array}{c}\text { Matched } \\
\text { sample (\%) }\end{array}$ \\
\cline { 2 - 3 } & Control & Beneficiaries & san \\
Male & 50.6 & 48.2 & 48 \\
Female & 49.4 & 51.8 & 52 \\
\hline Total & 100.0 & 100.0 & 100 \\
\hline
\end{tabular}

Source: ProJoven Database (MTPE 2002).

Elaboration: owner.

Moreover, the employment status of the samples of matched beneficiaries and controls are similar. Figure 3 depicts the distributions of employment status for both groups.

The second step in the matching procedure was designed to reduce the differences in labor income that existed between beneficiaries and controls prior to implementation of ProJoven. While the original samples of beneficiaries and controls reveal higher earnings for the latter, the gap is reduced in the expanded matched sample. For hourly wages, the average difference between beneficiaries and controls is around six cents of a Nuevo Sol, representing approximately $5 \%$ of the beneficiaries' average payment rate. These results are reported in table 4 . 
Figure 3

Beneficiaries and controls by employment status, expanded matched sample (in percent)

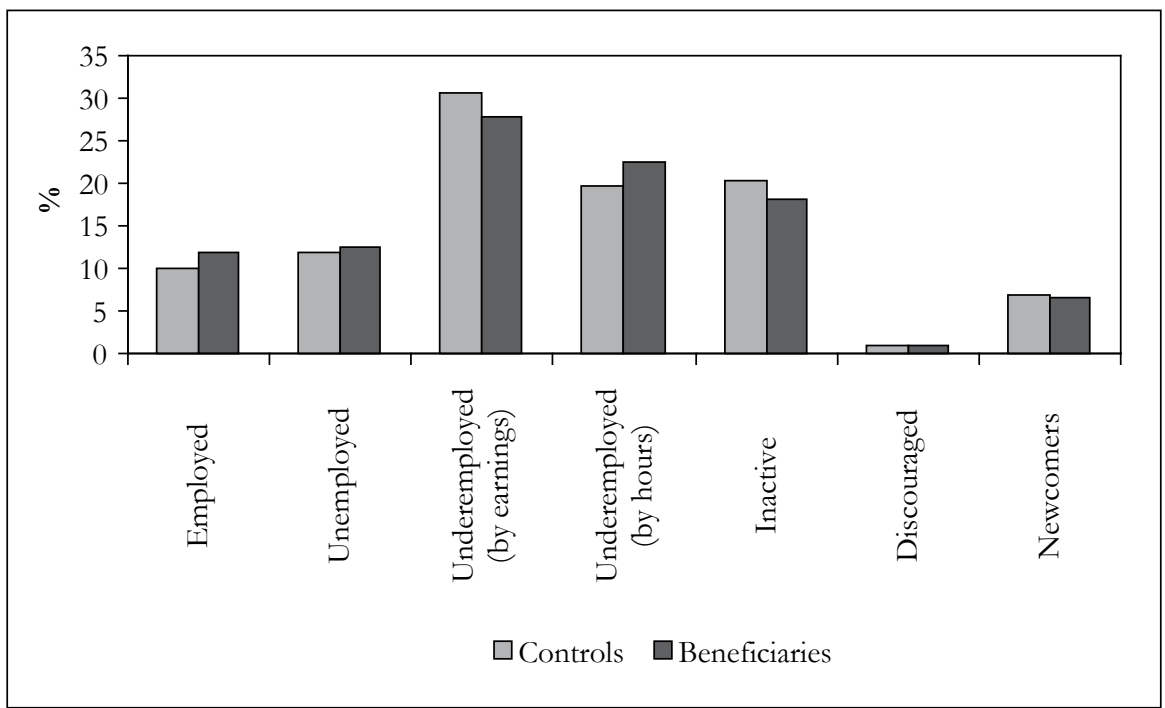

Source: ProJoven Database (MTPE 2002).

Elaboration: owner.

Table 4

Monthly earnings and hourly wages for beneficiaries and controls at the baseline

\begin{tabular}{lcccc}
\hline & \multicolumn{2}{c}{ Monthly earnings } & \multicolumn{2}{c}{ Hourly wages } \\
\cline { 2 - 5 } & Mean & Std. Dev. & Mean & Std. Dev. \\
\hline Controls (original sample) & 252.80 & 165.61 & 1.41 & 0.98 \\
Controls (matched sample) & 216.83 & 144.04 & 1.10 & 0.67 \\
Controls (expanded matched sample) & 228.13 & 157.46 & 1.14 & 0.72 \\
\hline Beneficiaries (original sample) & 165.09 & 144.22 & 1.03 & 0.82 \\
Beneficiaries (matched sample) & 172.93 & 145.89 & 1.05 & 0.76 \\
Beneficiaries (expanded matched sample) & 175.97 & 149.05 & 1.08 & 0.75 \\
\hline
\end{tabular}

Source: ProJoven Database (MTPE 2002).

Elaboration: owner.

\section{RESULTS}

The impact of ProJoven on labor market outcomes was measured for four aspects: labor supply (measured by employment rates and hours worked), income (measured by hourly wages and monthly earnings), occupational segregation by gender (measured by 
the Duncan Index ${ }^{3}$ ) and other effects. The impact estimators we report are computed as differences-in-differences. ${ }^{4}$

For the three months for which there are measurements we have information about individuals' primary and secondary jobs. In addition, participants were asked to record their labor situation (including employment status, occupation, hours worked and wage) for the primary occupation for the periods between interviews. Whenever possible, we report the development of labor variables for the beneficiaries and the corresponding control individuals for the 33 months $^{5}$ in which data was collected.

\subsection{THE IMPACT ON LABOR SUPPLY}

Since a main objective of ProJoven is to facilitate the process of participants entering the labor market, the first variables for measuring impact will be employment rates and hours worked.

\subsubsection{Employment rates}

The impact of ProJoven on the unemployment rate is negative for the first two measurements (at the six- and twelve-month marks after program completion), although the difference is very close to zero. After eighteen months there is a positive impact on the employment rate as can be seen in table 5. The estimated ProJoven impact is $3.24 \%$ in the employment rate. ${ }^{6}$

Table 5

Impact on employment rates of trainees vs. controls (in percent)

\begin{tabular}{lcccc}
\hline & Baseline & Six months & Twelve months & Eighteen months \\
\hline Controls & 57.9 & 65.3 & 66.2 & 64.6 \\
Beneficiaries & 59.1 & 64.8 & 65.6 & 69.1 \\
\hline ProJoven impact & & -1.74 & -1.87 & 3.24 \\
\hline
\end{tabular}

Source: ProJoven Database (MTPE 2002).

Elaboration: owner.

3 The Duncan Index is a measure of occupational segregation. It attains values on the interval $[0,1]$, where an index of 0 reflects no segregation (men and women are equally distributed across occupations) and 1 reflects complete segregation (some occupations are only for men and others only for women). The Duncan Index can be interpreted as the percentage of the female working force that would have to switch from female-dominated to male-dominated jobs to achieve an equal distribution of men and women across occupations.

4 Differences between matched beneficiaries and control individuals are computed on the baseline and are compared with the observable differences recorded six, twelve and eighteen months after completing the program.

5 Not all the courses started at the same time. Some were delayed and that's why we have three additional months in this account.

6 This and all the remaining impact estimators are diff-in-diff. For instance the impact estimator after six months is obtained from (64.8-59.1)-(65.3-57.9). 
Detailed monthly data provides better information about the labor effects of the program on individual beneficiaries and controls. The vertical lines in figure 4 refer to critical moments in the sixth class's development: the baseline (November 1999), the beginning of the training courses (February 2000), the end of training (October 2000), the sixth-month measurement (May 2001), the twelfth-month measurement (November 2001) and the eighteenth-month measurement (May 2002). However, it should be noted that the data points at times other than the survey times may suffer from recall bias.

Figure 4

Employment rates for beneficiaries and controls

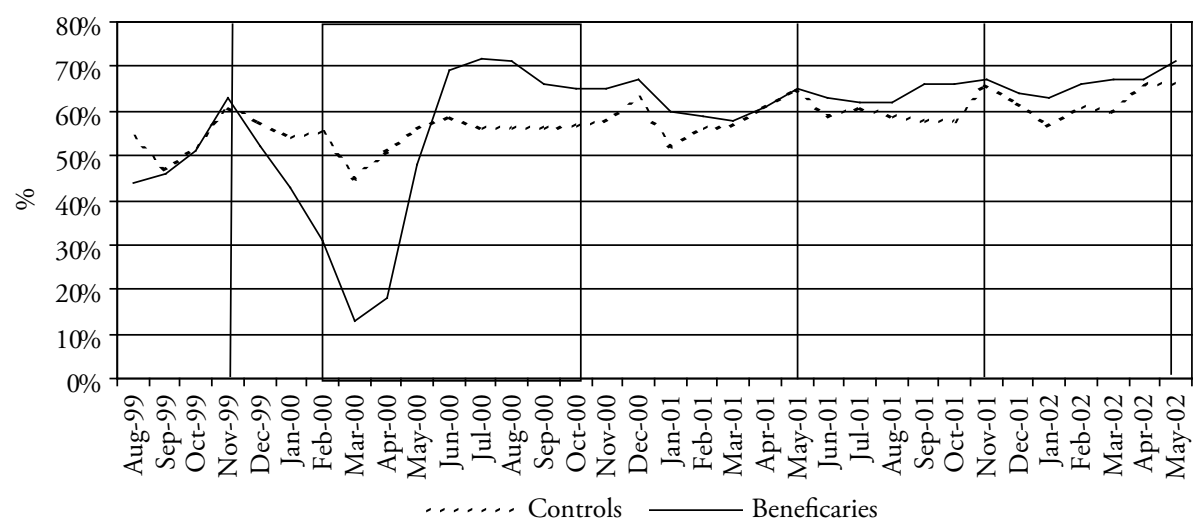

Source: ProJoven Database (MTPE 2002).

Elaboration: owner.

The employment rates for beneficiaries and controls coincided at the baseline. After the training period, the employment rate of beneficiaries was below that for the controls. When beneficiaries began their internships, their employment rate rose to $70 \%$ but inched down to $65 \%$ during the months following the program.

Although ProJoven's overall impact on employment is positive only after eighteen months, it produces important gender differences (table 6). As a result of their participation in the program, women achieved insertion into more jobs than men. The $5.96 \%$ increase in female employment twelve months after program completion and the $15.2 \%$ increase after eighteen months can be attributed to the women's participation in ProJoven.

Table 6

Impact on gender employment rates (in percent)

\begin{tabular}{lccc}
\hline & Six months & Twelve months & Eighteen months \\
\hline Women & -2.45 & 5.96 & 15.20 \\
Men & -0.88 & -11.36 & -11.26 \\
\hline
\end{tabular}

Source: ProJoven Database (MTPE 2002).

Elaboration: owner. 


\subsubsection{Hours worked}

Even though ProJoven's overall impact on the extensive margin of the labor supply (measured by employment rates) was close to zero, the impact on the intensive margin (measured by hours worked) was positive (table 7 and figure 5). ${ }^{7}$

Table 7

Impact on hours worked, main and secondary occupations (in percent)

\begin{tabular}{lcccc}
\hline & Baseline & Six months & Twelve months & Eighteen months \\
\hline Controls & 48.31 & 54.30 & 60.13 & 57.98 \\
Beneficiaries & 40.88 & 54.09 & 55.83 & 53.83 \\
\hline ProJoven impact & & $17.7 \%$ & $7.7 \%$ & $8.0 \%$ \\
\hline
\end{tabular}

Source: ProJoven Database (MTPE 2002).

Elaboration: owner.

Figure 5

Weekly hours worked in main occupation of beneficiaries and controls

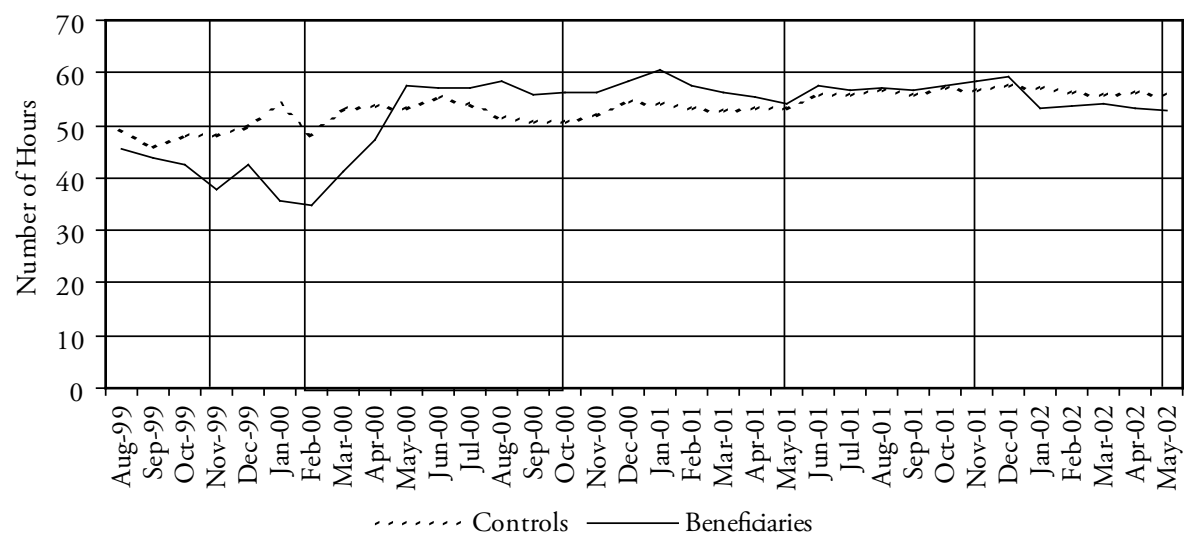

Source: ProJoven Database (MTPE 2002).

Elaboration: owner.

Although ProJoven did not substantially increase the participants' employment rate, beneficiaries did increase their weekly hours worked (table 8). Consequently, the program had a positive impact on weekly and monthly earnings. The breakdown of this impact by gender reveals a larger effect on men.

\footnotetext{
7 The percentage impact estimators are obtained from the diff-in-diff estimator explained in footnote 7 , computed as percentage of the average value for beneficiaries at the baseline.
} 
Table 8

Impact on hours worked by gender (in percent)

\begin{tabular}{lccc}
\hline & Six months & Twelve months & Eighteen months \\
\hline Women & 13.42 & 10.42 & 5.73 \\
Men & 21.86 & 9.73 & 14.64 \\
\hline
\end{tabular}

Source: ProJoven Database (MTPE 2002).

Elaboration: owner.

\subsection{IMPACT ON EARNINGS}

\subsubsection{Hourly Wages}

The impact of ProJoven on the hourly wages of young beneficiaries is positive and it slightly increases during the period of analysis, as can be seen in table 9 .

Table 9

Impact on hourly wages(main and secondary occupations)

\begin{tabular}{lcccc}
\hline & Baseline & Six months & Twelve months & Eighteen months \\
\hline Controls & S/.1.14 & S/.1.42 & S/.1.35 & S/.1.40 \\
Beneficiaries & S/.1.08 & S/.1.48 & S/.1.46 & S/.1.54 \\
\hline ProJoven impact & & $11.1 \%$ & $15.7 \%$ & $18.5 \%$ \\
\hline
\end{tabular}

Source: ProJoven Database (MTPE 2002).

Elaboration: owner.

Next we show the evolution of the beneficiaries' and controls' average hourly wages from their main occupations. The impact of ProJoven in the sixth month is negative, however at the twelfth and eighteenth month it is positive (see figure 6).

Table 10 shows gender differences in ProJoven's impact on hourly wages. After the twelfth month, men are benefiting more than women. However, at the sixth and eighteenth months, gender differences in income per hour are minor.

Table 10

Impact on hourly wages by gender (in percent)

\begin{tabular}{lccc}
\hline & Six months & Twelve months & Eighteen months \\
\hline Women & 10.83 & 5.03 & 19.99 \\
Men & 10.04 & 25.36 & 20.78 \\
\hline
\end{tabular}

Source: ProJoven Database (MTPE 2002).

Elaboration: owner. 
Figure 6

Main occupation hourly wages of beneficiaries and controls

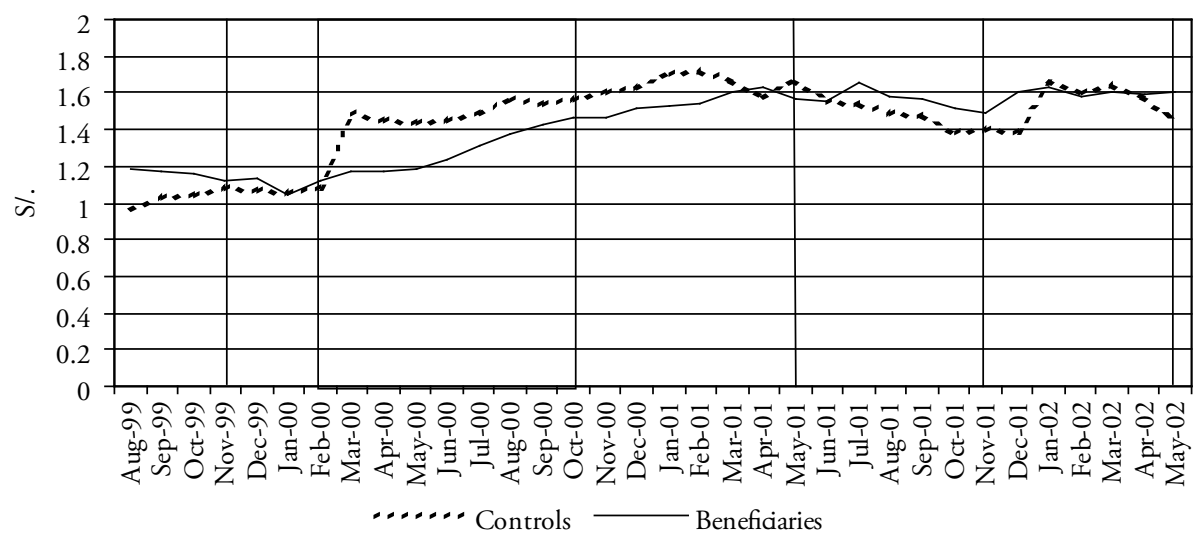

Source: ProJoven Database (MTPE 2002).

Elaboration: owner.

\subsubsection{Monthly Earnings}

ProJoven's effect on average monthly earnings is obtained by adding the monetary value of the effect from number of hours worked to the effect on hourly wages. ProJoven has a positive impact on both variables, which are also positively correlated. Consequently, the aggregate effect is greater than what would be obtained from a simple aggregation of the individual effects. The impact of ProJoven at the sixth month reaches $48 \%$ of average monthly earnings (table 11). The impact reduces by the eighteenth month to a still-noticeable $30 \%$.

Table 11

Impact on average monthly earnings (main and secondary occupations)

\begin{tabular}{lcrrr}
\hline & Baseline & Six months & Twelve months & Eighteen months \\
\hline Controls & S/.228.13 & S/.285.95 & S/.319.30 & S/.330.02 \\
Beneficiaries & S/.175.97 & S/.325.50 & S/.330.92 & S/.333.72 \\
\hline ProJoven impact & & $52.1 \%$ & $36.2 \%$ & $31.7 \%$ \\
\hline
\end{tabular}

Source: ProJoven Database (MTPE 2002).

Elaboration: owner.

The evolution of average monthly earnings of beneficiaries and controls also reveals a positive, if limited, effect on the average monthly earnings of program participants (figure 7). The beneficial effects only relate to the primary occupation and in fact disappear during the last five months of measurement. 
The impact of ProJoven on aggregate labor income incorporates the effects on individual labor income and employment, as shown in table 12. At the baseline, it is estimated that the expanded sample of beneficiaries generated S/. 375,558, while the expanded sample of controls generated S/. 476,646. Six months after program completion, the total labor income of beneficiaries grew to $S / .761,918$, while the controls earned S/. 674,486. This implies a positive effect of almost 50\% (see footnotes 7 and 8 ) over beneficiary baseline income.

Figure 7

Average monthly earnings from main occupations of beneficiaries and controls

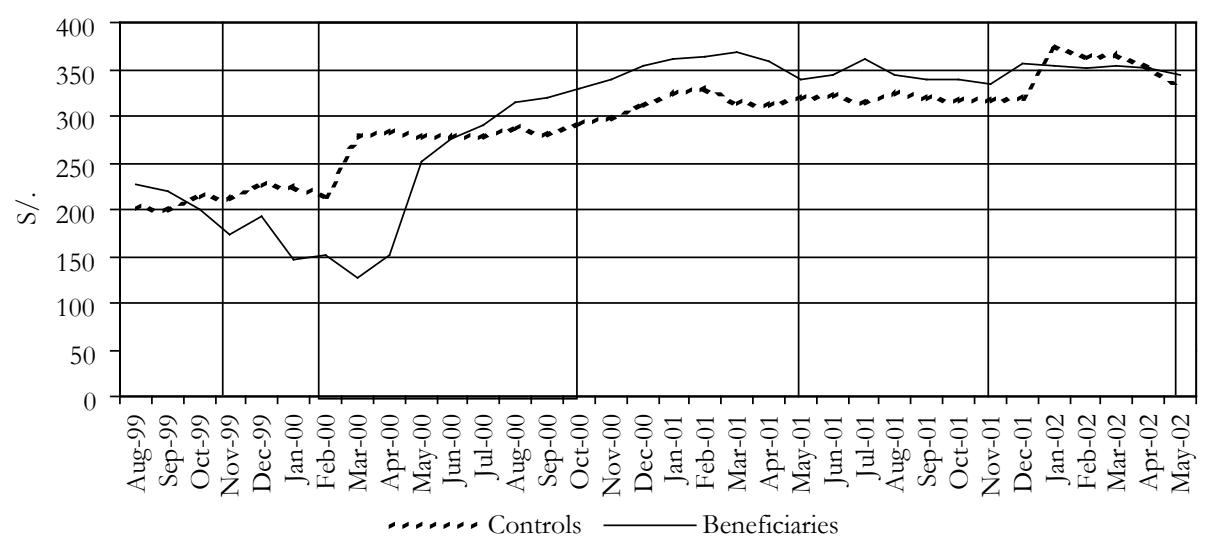

Source: ProJoven Database (MTPE 2002).

Elaboration: owner.

Table 12

Impact on total monthly earnings(main and secondary occupations)

\begin{tabular}{lcrrr}
\hline & Baseline & Six months & Twelve months & Eighteen months \\
\hline Controls & S/. 476,646 & S/. 674,486 & S/. 763,629 & S/. 766,668 \\
Beneficiaries & S/. 375,558 & S/. 761,918 & S/. 783,860 & S/. 832,423 \\
\hline ProJoven impact & & $50.2 \%$ & $32.3 \%$ & $44.4 \%$ \\
\hline
\end{tabular}

Source: ProJoven Database (MTPE 2002).

Elaboration: owner.

Table 13 shows the gender breakdown of ProJoven's impact on monthly earnings, revealing substantial gains for women. After eighteen months, beneficiary women generate $92.88 \%$ more labor income than their control counterparts. Also, while the impact on men diminishes over time after graduation, the effect for women does not vanish. 
Table 13

Impact on total monthly earnings by gender (in percent)

\begin{tabular}{lccc}
\hline & Six months & Twelve months & Eighteen months \\
\hline Women & 46.57 & 49.70 & 92.88 \\
Men & 41.31 & 17.38 & 10.92 \\
\hline
\end{tabular}

Source: ProJoven Database (MTPE 2002).

Elaboration: owner.

\subsection{IMPACT ON OCCUPATIONAL SEGREGATION}

ProJoven has been able to reduce occupational segregation among its targeted population. The program encourages training entities to focus on increasing female worker participation in the labor market, especially in occupations with a high prevalence of male workers. Women trainees who had been working in occupations traditionally filled by women, or who were previously unemployed, subsequently found jobs in occupations traditionally filled by men. Important changes can be documented in the percentages of female participation in three occupational groups: sales personnel, restaurant and food service workers, and domestic workers. As a result of participation in ProJoven, the levels of occupational segregation, measured by the Duncan Index, diminished noticeably among the beneficiaries.

Table 14

Occupational segregation by gender before and after ProJoven

(Duncan Index)

\begin{tabular}{lcccc}
\hline & Baseline & Six months & Twelve months & Eighteen months \\
\hline Controls & 0.681 & 0.610 & 0.638 & 0.732 \\
Beneficiaries & 0.626 & 0.467 & 0.508 & 0.461 \\
\hline
\end{tabular}

Source: ProJoven Database (MTPE 2002).

Elaboration: owner.

Bootstrapping the estimation of the distribution of such Duncan Indexes assures that the changes in occupational segregation are significantly positive. Changes in the occupational structures of beneficiaries do not weaken after eighteen months. In fact, the effect is accentuated slightly as illustrated by figure 8 . Note that the distributions of the index for beneficiaries and controls separate from each other. 
Figure 8

Density functions for the Duncan Index (estimated from 2000 bootstrap iterations)

Before ProJoven

(Baseline)

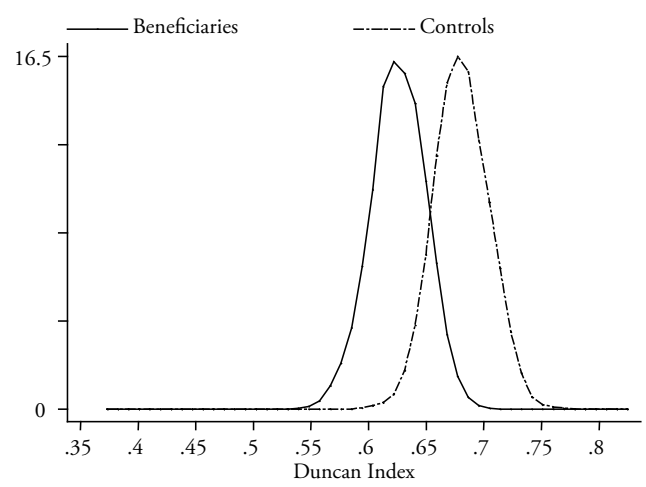

Twelve months after

ProJoven

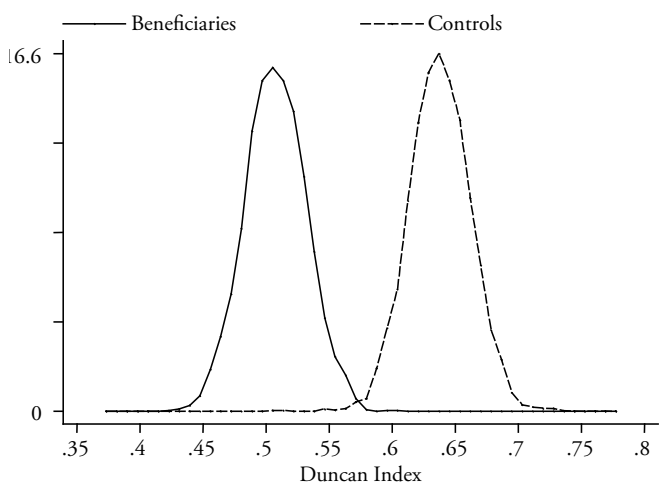

Six months after

ProJoven

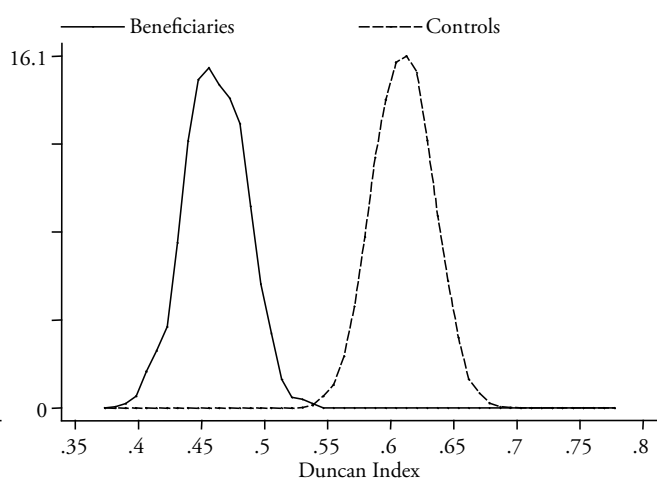

Eighteen months after

ProJoven

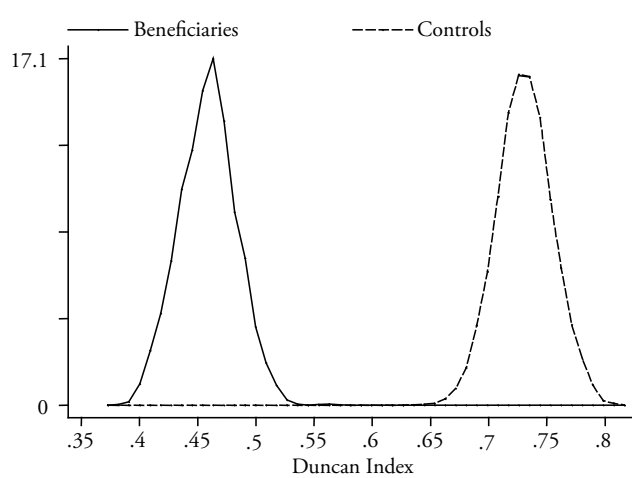

Source: ProJoven Database (MTPE 2002).

Elaboration: owner.

\subsection{OTHER EFFECTS}

Apart from the effects that ProJoven has had on trainees' employment status, earnings and occupational segregation, other variables related to the working conditions and the well-being of its beneficiaries should be discussed. Indeed, ProJoven graduates experienced positive changes in the characteristics of the firms that hire them, the type of job contracts they receive, workplace conditions and reduction of secondary activities.

ProJoven training and apprenticeships led beneficiaries toward work in larger firms. Prior to joining the program, $11.76 \%$ of individuals were working in firms with 21 employees or more, while $36.22 \%$ are so employed six months after having completed 
their apprenticeships, a level that is maintained at the twelve-month and eighteenmonth marks.

The percentage of individuals working under permanent or temporary contracts also increases after leaving ProJoven, indicating better working conditions for program beneficiaries. At the baseline, 13.9\% of enrollees were working under one of these contract types, compared to $43.4 \%$ six months after completion of the program and $46.8 \%$ and $56.3 \%$ after twelve and eighteen months, respectively.

We also observe changes in place of employment. After completing the program, beneficiaries tend to stop working at home or the homes of friends and begin working at firms. These changes are more pronounced for the trainee sample than for the control group. Before participation in ProJoven, 35.2\% of beneficiaries worked in formal places compared to $65.3 \%$ afterwards.

Finally, ProJoven has positively affected the percentage of workers who have secondary jobs and the number of hours devoted to each occupation. At the baseline, $11.31 \%$ of participants had a secondary occupation compared with $4.38 \%$ after completing the program. Moreover, the differences-in-differences estimator shows that beneficiaries reduced the number of hours devoted to secondary occupations by $70 \%$ by the sixthmonth mark and by $46 \%$ at the eighteenth-month mark.

\section{CONCLUSIONS}

This paper provides evidence that a training program promoting gender equality has disproportionately higher impact for women than for men. ProJoven promotes equal gender participation in its training courses and generates incentives for young women with children to participate by providing special subsidies. As a result, ProJoven improves the employment rate of women more than men; and female trainees find their way in the labor market in a less segregated way. Program participants also work more hours per week after their training, although this result is more typical for men than women. The program positively impacts hourly wages, without gender differences. The combined effects (employment status, occupational field, hours worked and hourly wages), which are reflected in the total labor income of participants, is positive overall, but substantially higher for women than for men.

The paper also demonstrates the practicality of applying a non-experimental program evaluation design that combines political feasibility and statistical soundness. The political feasibility of implementing the model stems from the absence of need to perform any random assignment of individuals to the beneficiary and control groups (an activity that policymakers are always reluctant to undertake). On the other hand, it requires detailed fieldwork, complemented with propensity score matching. Statistically, the differences in observable characteristics between the beneficiary and control groups are smaller than those that would be obtained with a traditional procedure. If the 
unobservable characteristics of individuals in both groups were correlated to observable characteristics, the performance of the estimators obtained with this procedure could be comparable to the performance of estimators obtained with experimental frameworks. However, this is a conditional assessment. The way to guarantee a proper construction of treatment and control groups is through a randomized assignment.

\section{APPENDIX}

Table A1.

Estimation of the propensities to participate at ProJoven by city

\begin{tabular}{lccccc}
\hline \multicolumn{1}{c}{ Variables } & Arequipa & Chiclayo & Lima & Cusco & Trujillo \\
\hline Log of hourly wage & 0.037 & -0.022 & 0.008 & 0.036 & -0.000 \\
& $(2.75)^{* *}$ & $(0.74)$ & $(0.58)$ & $(2.96)^{* *}$ & $(0.02)$ \\
Male = 1 & -0.216 & -0.011 & -0.036 & -0.008 & 0.096 \\
Age & $(1.91)$ & $(0.08)$ & $(0.40)$ & $(0.05)$ & $(0.90)$ \\
& 0.022 & 0.046 & -0.001 & 0.126 & 0.021 \\
Tenure (weeks) & $(0.87)$ & $(1.23)$ & $(0.03)$ & $(3.36)^{* *}$ & $(0.93)$ \\
& -0.001 & -0.002 & -0.001 & -0.001 & -0.002 \\
Finished high school = 1 & $(0.54)$ & $(1.63)$ & $(2.16)^{*}$ & $(0.82)$ & $(3.00)^{* *}$ \\
Went to a public school $=1$ & 0.110 & 0.039 & -0.080 & -0.438 & -0.104 \\
Took vocational training $=1$ & $(0.70)$ & $(0.20)$ & $(0.70)$ & $(2.24)^{*}$ & $(0.96)$ \\
Single = 1 & 0.177 & 0.088 & -0.205 & -0.262 & -0.133 \\
& $(0.75)$ & $(0.26)$ & $(0.96)$ & $(1.23)$ & $(0.82)$ \\
Has children = 1 & 0.098 & 0.807 & 0.183 & 0.516 & 0.215 \\
Poverty score & $(0.88)$ & $(2.36)^{*}$ & $(1.87)$ & $(3.17)^{* *}$ & $(1.76)$ \\
Has a secondary job = 1 & 0.700 & 0.689 & 0.488 & 0.745 & 0.463 \\
Mother with college degree $=1$ & $(3.31)^{* *}$ & $(1.90)$ & $(3.15)^{* *}$ & $(2.53)^{*}$ & $(2.52)^{*}$ \\
& -0.228 & 0.138 & -0.147 & -0.320 & 0.130 \\
& $(1.14)$ & $(0.40)$ & $(1.00)$ & $(1.07)$ & $(0.71)$ \\
& 1.093 & 1.094 & 0.910 & 0.513 & 1.240 \\
& $(6.06)^{* *}$ & $(2.74)^{* *}$ & $(4.36)^{* *}$ & $(1.52)$ & $(6.01)^{* *}$ \\
& 0.183 & 0.393 & 0.869 & 0.905 & 0.763 \\
& $(0.53)$ & $(1.28)$ & $(3.38)^{* *}$ & $(2.86)^{* *}$ & $(2.47)^{*}$ \\
& -0.018 & 0.067 & 0.016 & -0.012 & 0.007 \\
& $(1.32)$ & $(3.18)^{* *}$ & $(1.24)$ & $(0.44)$ & $(0.41)$ \\
\hline & & & & & \\
& & & & & \\
& & &
\end{tabular}




\begin{tabular}{|c|c|c|c|c|c|}
\hline Variables & Arequipa & Chiclayo & Lima & Cusco & Trujillo \\
\hline \multirow{2}{*}{$\begin{array}{l}\text { Log of the average hourly wage during } \\
\text { the last three months }\end{array}$} & -0.131 & -0.104 & -0.114 & -0.043 & -0.224 \\
\hline & $(2.67)^{* *}$ & $(1.06)$ & $(2.70)^{* *}$ & $(0.85)$ & $(2.23)^{*}$ \\
\hline \multirow[t]{2}{*}{ EEE } & 0.938 & 0.211 & 0.797 & -0.295 & 1.664 \\
\hline & $(2.80)^{* *}$ & $(0.32)$ & $(2.72)^{* *}$ & $(0.83)$ & $(2.46)^{*}$ \\
\hline \multirow[t]{2}{*}{ EUE } & 1.078 & 0.475 & 1.113 & & 1.609 \\
\hline & $(2.66)^{* *}$ & $(0.61)$ & $(2.46)^{*}$ & & $(2.33)^{*}$ \\
\hline \multirow[t]{2}{*}{ EEU } & 0.660 & 0.412 & 0.822 & 0.431 & 1.728 \\
\hline & (1.69) & $(0.61)$ & $(2.53)^{*}$ & $(0.78)$ & $(2.48)^{*}$ \\
\hline \multirow[t]{2}{*}{ EUU } & 1.139 & 1.093 & 0.576 & 0.547 & 1.813 \\
\hline & $(2.52)^{*}$ & $(1.41)$ & (1.67) & $(1.01)$ & $(2.64)^{* *}$ \\
\hline \multirow[t]{2}{*}{ UUE } & 0.702 & 0.542 & 0.818 & -0.084 & 1.552 \\
\hline & $(1.73)$ & $(0.76)$ & $(2.37)^{*}$ & $(0.17)$ & $(2.19)^{*}$ \\
\hline \multirow[t]{2}{*}{ UEE } & 0.777 & 0.366 & 0.623 & 1.285 & 1.674 \\
\hline & $(1.83)$ & $(0.52)$ & $(1.70)$ & $(2.20)^{*}$ & $(2.31)^{*}$ \\
\hline \multirow[t]{2}{*}{ UEU } & 1.392 & 0.813 & -0.212 & & 1.643 \\
\hline & $(2.60)^{* *}$ & $(0.79)$ & $(0.32)$ & & $(1.82)$ \\
\hline \multirow[t]{2}{*}{ Constant } & -2.752 & -3.987 & -1.579 & -3.131 & -3.317 \\
\hline & $(3.79)^{* *}$ & $(3.26)^{* *}$ & $(2.68)^{* *}$ & $(3.33)^{* *}$ & $(3.57)^{* *}$ \\
\hline Observations & 834 & 481 & 1,012 & 464 & 1,019 \\
\hline Pseudo R2 & 0.12 & 0.11 & 0.07 & 0.17 & 0.08 \\
\hline
\end{tabular}

Source: ProJoven Database (MTPE 2002).

Elaboration: owner.

Notes: t-statistics are in parentheses. ${ }^{*}$ Significant at $5 \%$; ${ }^{* *}$ Significant at $1 \%$. 


\section{REFERENCES}

Ashenfelter, Orley

1978 «Estimating the Effect of Training Programs on Earnings». The Review of Economics and Statistics, Vol. 6, $\mathrm{N}^{\circ} 1$, pp. 47-57, Cambridge.

Heckman, James, Hidehiko Ichimura and Petra Todd

1997 «Matching as an Econometric Evaluation Estimator: Evidence from Evaluating a Job Training Program». The Review of Economics Studies, Vol. 64, N²21, pp. 605-650, Oxford.

Heckman, James and Jeffrey Smith

1999 The Pre-Program Earnings Dip and the Determinants of Participation in a Social Program: Implications for Simple Program Evaluation Strategies. Working Paper No 6983. Cambridge: National Bureau of Economic Research. Available at <http://www.nber.org/papers/w6983>

Heckman, James, Robert Lalonde and Jeffrey Smith

1999 "The Economics and Econometrics of Active Labor Market Programs». In Orley Ashenfelter and David Card (editors). Handbook of Labor Economics, Vol. III, Chapter 31, pp. 1865-2097. Amsterdam: Elsevier.

López-Acevedo, Gladys

2002 Wages and Productivity in Mexican Manufacturing. Mimeographed document. Mexico, D.F.: World Bank.

MTPE - Ministerio de Trabajo y Promoción del Empleo

2002 ProJoven Database.

Ñopo, Hugo

(Forthcoming) «Matching as a Tool to Decompose Wage Gaps». The Review of Economics and Statistics, Cambridge.

Ñopo, Hugo, Miguel Robles and Jaime SAAVEdra

2002 Una medición del impacto del programa de capacitación laboral juvenil ProJoven. Working Paper $N^{\circ}$ 36. Lima: GRADE. 